Hydrol. Earth Syst. Sci., 17, 4061-4077, 2013

www.hydrol-earth-syst-sci.net/17/4061/2013/

doi:10.5194/hess-17-4061-2013

(c) Author(s) 2013. CC Attribution 3.0 License.

\title{
Geometric dependency of Tibetan lakes on glacial runoff
}

\author{
V. H. Phan ${ }^{1,2}$, R. C. Lindenbergh ${ }^{1}$, and M. Menenti ${ }^{1}$ \\ ${ }^{1}$ Department of Geosciences and Remote Sensing, Delft University of Technology, Stevinweg 1, \\ 2628 CN Delft, the Netherlands \\ ${ }^{2}$ Department of Geomatics Engineering, Ho Chi Minh city University of Technology, 268 Ly Thuong Kiet St., \\ Dist. 10, Ho Chi Minh City, Vietnam
}

Correspondence to: V. H. Phan (v.phanhien@tudelft.nl)

Received: 12 December 2012 - Published in Hydrol. Earth Syst. Sci. Discuss.: 17 January 2013

Revised: 22 August 2013 - Accepted: 14 September 2013 - Published: 21 October 2013

\begin{abstract}
The Tibetan Plateau is an essential source of water for Southeast Asia. The runoff from its $~ 34000$ glaciers, which occupy an area of $\sim 50000 \mathrm{~km}^{2}$, feeds Tibetan lakes and major Asian rivers like the Indus and Brahmaputra. Reported glacial shrinkage likely has an impact on the runoff. Unfortunately, accurate quantification of glacial changes is difficult over the high-relief Tibetan Plateau. However, it has recently been shown that it is possible to directly assess water level changes of a significant number of the $\sim 900$ Tibetan lakes with an area over $1 \mathrm{~km}^{2}$. This paper exploits different remote sensing products to create drainage links between Tibetan glaciers, lakes and rivers. The results allow us to differentiate between lakes with and without outlet. In addition, we introduce the notion of geometric dependency of a lake on glacial runoff, defined as the ratio between the total area of glaciers draining into a lake and the total area of the lake catchment. We determined these dependencies for all $\sim 900$ sufficiently large Tibetan lakes. To do so, we combined three remote sensing products: the CAREERI glacier mask product, a lake mask product based on the MODIS MOD44W water product and the HydroSHEDS river network product derived from Shuttle Radar Topography Mission (SRTM) elevation data. Using a drainage network analysis, we determined all drainage links between glaciers and lakes. The results show that $25.3 \%$ of the total glacier area directly drains into one of 244 Tibetan lakes. The results also give the geometric dependency of each lake on glacial runoff. For example, there are ten lakes with direct glacial runoff from at least $240 \mathrm{~km}^{2}$ of glacier. Three case studies, including one of the well-studied Nam Tso Lake, demonstrate how the geometric dependency of a lake on glacial runoff can be directly linked to hydrological processes.
\end{abstract}

\section{Introduction}

The Tibetan Plateau is the highest and largest plateau in the world, and contains a large number of glaciers. It also contains more than one thousand lakes and is the origin of a large part of the water resources of South and East Asia, the most densely populated regions on Earth. Recent studies concluded that the glacial area on the Tibetan Plateau and its surroundings has decreased significantly in recent decades. According to Yao et al. (2012), the amount of glacier change in the last $30 \mathrm{yr}$ is location dependent, with the largest reduction in glacial length and area occurring in the Himalayas (excluding the Karakoram). Sorg et al. (2012) showed that glacier shrinkage also occurred at the Tien Shan Mountains in the north-west of Tibet between 1950 and 2000. As reported in Wang et al. (2011), 910 glaciers in the Middle Qilian Mountain region rapidly reduced in area between 1956 and 2003, with a mean reduction of $0.10 \mathrm{~km}^{2}$ per individual glacier, corresponding to an average rate of $2127 \mathrm{~m}^{2} \mathrm{yr}^{-1}$. Glaciers in the Tuotuo River basin, the source of the Yangtze River in the inner plateau, also retreated between 1968 and 2002 (Zhang et al., 2008) as have glaciers in the Mt. Qomolangma (Mt. Everest) region in the Himalayas in the last $35 \mathrm{yr}$ (Ye et al., 2009). Kaab et al. (2012) quantified the glacial thinning in the Hindu Kush-Karakoram-Himalaya region from 2003 to 2008 using satellite laser altimetry and a global elevation model. Gardelle et al. (2012) compared two digital elevation models between 1999 and 2008 and revealed that ice thinning and ablation is occurring at high rates in the central Karakoram and the Himalaya mountain ranges. These glacier reductions will directly affect water level changes on the Tibetan Plateau and its surroundings. 
In addition to monitoring glacier changes, researchers have also studied lake level fluctuations on the Tibetan Plateau. As described in recent reports (Zhang et al., 2011; Phan et al., 2012a; Wang et al., 2013), studies estimated roughly 150 water level trends in the Tibetan lakes sampled by the ICESat/GLAS LIDAR campaigns between 2003 and 2009. The results indicate that the water level of most lakes on the southern Tibetan Plateau and along the Himalaya mountain range shows a serious downwards trend. Lakes with a positive water level trend during the observed period are mostly located on the inner plateau. Phan et al. (2012b) showed that seasonal variations in lake levels and lake level trends differ considerably for different parts of the Tibetan Plateau. Besides, Zhang et al. (2013) correlated water mass increases derived from GRACE data to positive lake level trends.

Glacial runoff is only one component contributing to the water levels of the lakes on the Tibetan Plateau. Water levels are also affected by rainfall, snow melt, underground water, evaporation and lake water runoff. Hydrological models can be used to estimate the amount of glacier meltwater flowing into a lake. At the moment, it is only possible to establish these hydrological models for selected basins, simply because the necessary measurements are not available for most of the Tibetan Plateau. As demonstrated in this paper, however, it is possible to determine all geometric links between Tibetan lakes and glaciers. This enables us to determine to what level each lake is geometrically dependent on glacial runoff. This work will constrain the modeling of hydrological processes and will also provide an indirect way to monitor the state of the Tibetan glaciers, as monitoring lake levels is easier than monitoring glacial changes in a high-relief environment. We believe that a regional approach, like this work, is needed to start understanding the spatial variations in glacial mass changes that are reported in current literature.

\section{Data and methods}

In this section, we introduce all used data products, data format conversions and coordinate systems. We define geospatial notions such as lake catchment, lake outlet, connection between glacier and lake, etc. Then, we show how to determine connections between glaciers and lakes. Finally, we describe indicators for the geometric dependency of a Tibetan lake on glaciers and methods for the computation of this dependency.

\subsection{Data}

The main data sources used in this paper are the MODIS land-water mask, the CAREERI glacier mask, and the HydroSHEDS river network and drainage basin data. The water mask gives the locations of the Tibetan lakes. The glacier mask gives the outlines of the Tibetan glaciers. The river data provides information on the direction of surface runoff, while the drainage basin data describes the catchment areas on the Tibetan Plateau. The river network is used to analyze the connections between glaciers and lakes. For integration, all these data are projected onto the WGS84 Geographic Coordinate System.

\subsubsection{The MODIS land-water mask}

The water mask, called MODIS MOD44W $250 \mathrm{~m}$, was produced using over $8 \mathrm{yr}$ of Terra MODIS spectral data, over 6 yr of Aqua MODIS spectral data and Shuttle Radar Topography Mission (SRTM) elevation data (GLCF, 2012). For each pixel, the MODIS land-water mask indicates in different ways whether one of the contributing algorithms decided that the pixel represents water. In addition to lakes, the mask also shows some parts of rivers. The lakes in the mask are compared to Google Earth and appropriate Landsat TM images to remove parts of rivers and empty depressions or holes. For this study, we selected lakes with an area over $1 \mathrm{~km}^{2}$. This limits a trade-off: selecting only larger lakes would decrease the number of lakes in the analysis, while applying a lower threshold would stretch the possibilities of the $250 \mathrm{~m}$ MODIS land-water mask too much. This selection returns 891 lakes with an area over $1 \mathrm{~km}^{2}$ on the Tibetan Plateau. They occupy a total area of approximately $38800 \mathrm{~km}^{2}$, as shown in Fig. 1.

\subsubsection{The CAREERI glacier mask}

The glacier mask was developed by the World Data Center for Glaciology and Geocryology, Lanzhou (WDC, 2012). The product is distributed as ArcInfo coverage data, a GIS file format. It uses the Projected Coordinate System, based on the Krasovsky spheroid and the Albers map projection, as detailed in its metadata file. Its attributes consist of the area of each glacier $\left(\mathrm{m}^{2}\right)$, perimeter $(\mathrm{m})$, and glacier identification codes. The glacier inventory was based on both remote sensing and in situ data from 1978 to 2002 (Shi et al., 2009). The original data was collected and digitized by the Cold and Arid Regions Environmental and Engineering Research Institute, Chinese Academy of Science (CAREERI). The data accuracy is not described in the metadata. To enable integration into this application, we project the glacier coverage onto the WGS84 Geographic Coordinate System using a map conversion tool in ArcGIS. The glacier mask contains 34676 glaciers, stored as polygons that represent the glacier boundaries on the Tibetan Plateau. The total area of the glaciers is approximately $53236 \mathrm{~km}^{2}$, as shown in Fig. 1 .

\subsubsection{The HydroSHEDS river and drainage basin data}

HydroSHEDS stands for Hydrological data and maps based on SHuttle Elevation Derivatives at multiple Scales (HydroSHEDS) (USGS, 2012). HydroSHEDS provides hydrographic information in a consistent and comprehensive format for regional and global-scale applications. HydroSHEDS 


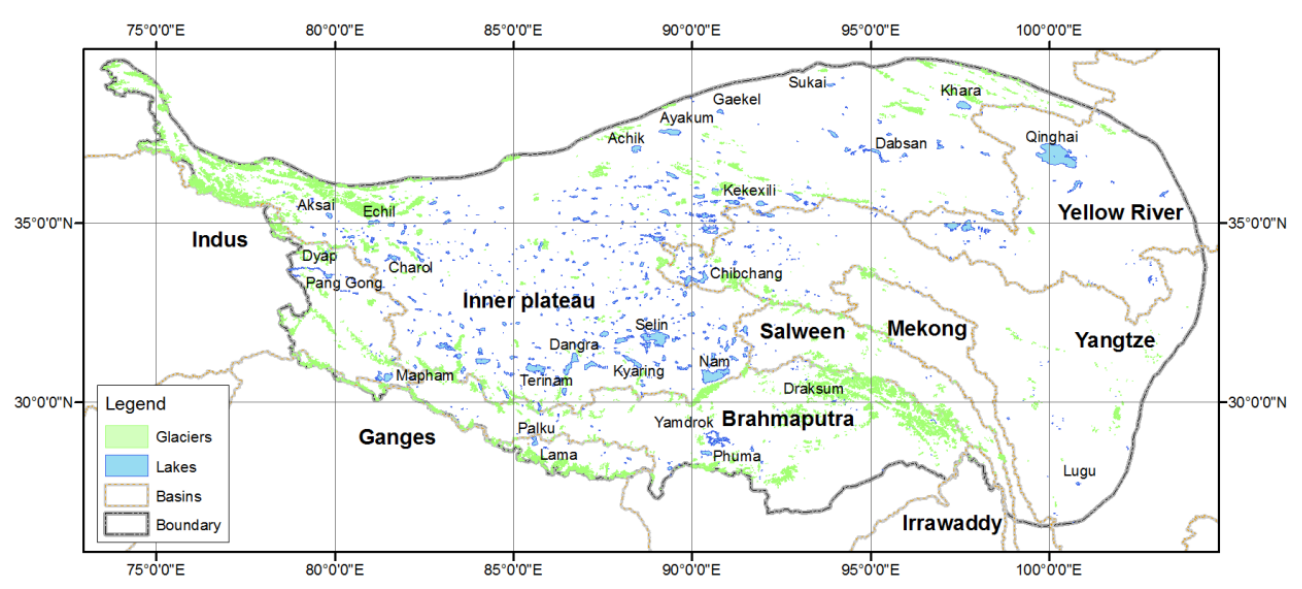

Fig. 1. Glaciers and lakes on the Tibetan Plateau.

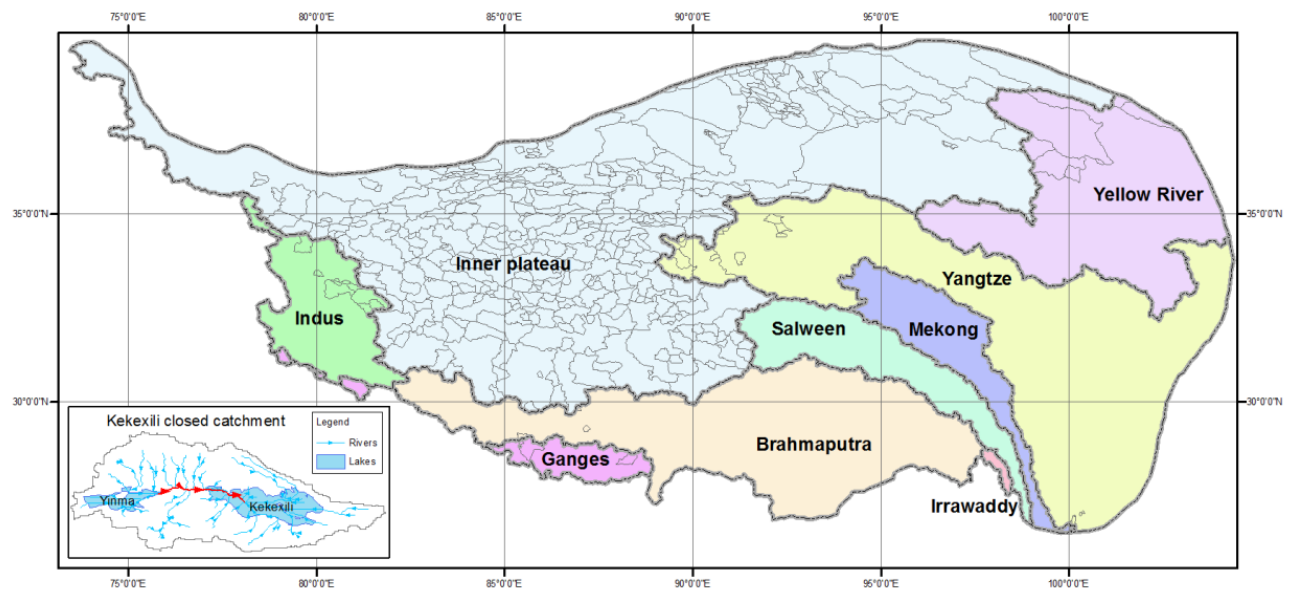

Fig. 2. Tibetan catchments derived from HydroSHEDS. Inset: the river network at the Kekexili catchment.

offers a suite of geo-referenced data sets (vector and raster), including stream networks, watershed boundaries, drainage directions and ancillary data layers such as flow accumulations, distances and river topology information. It is derived from elevation data of the STRM at 3 arcsecond resolution (a grid cell size of approximately $87 \mathrm{~m}$ on the Tibetan Plateau). The processing methods include void filling, filtering, stream burning, and up-scaling techniques. Manual corrections were made where necessary (Lehner et al., 2008).

The HydroSHEDS river data are directly derived from drainage directions and flow accumulation layers. The river data are built at 15 arcsecond resolution (approximately $410 \mathrm{~m}$ on the Tibetan Plateau). Grid cells with an upstream drainage area exceeding a threshold of 100 upstream cells were considered as belonging to a stream or a river segment. The river data are formatted in polyline vectors where each line is formed by a from-node (starting point), a list of vertices and a to-node (end point). The river network is referenced to WGS84. Each river segment has a pointer to its corresponding flow accumulation given as a number of grid cells. For example, the inset in Fig. 2 shows the river network in the Kekexili Lake catchment, and the flow route from Yinma Lake to Kekexili Lake is indicated.

The HydroSHEDS drainage basin data, describing the catchment areas or the watershed boundaries, are also built at 15 arcsecond resolution. This product is formatted as polygons, as shown in Fig. 2. It is also referenced to WGS84. Catchments are attributed with an area in square kilometer, e.g. the Kekexili Lake catchment occupies an area of $2636.5 \mathrm{~km}^{2}$.

There are discrepancies between the CAREERI glacier mask, the MODIS MOD44W land-water mask and the HydroSHEDS data. This is illustrated in Fig. 3, where the CAREERI glacier outlines, the MODIS lakes and the HydroSHEDS river segments and drainage basins are superimposed over a true-color image composed from bands 1, 2, and 3 of Landsat-ETM+, collected on 26 August 2002. It is evident that the CAREERI glacier positions do not fully overlap with the location of the glaciers as visible on the Landsat image. In this example, maximum differences are 


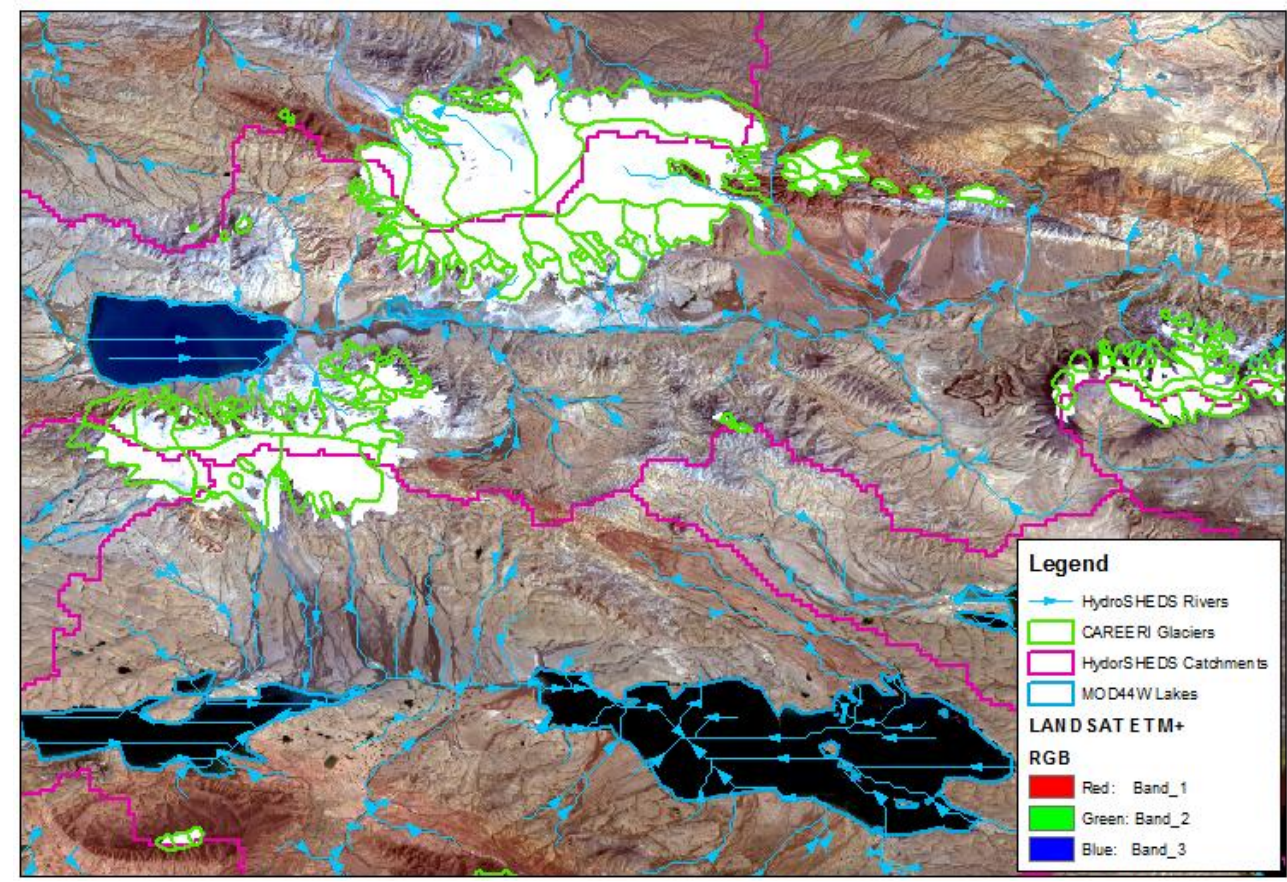

Fig. 3. CAREERI glacier mask data, MODIS MOD44W land-water mask data and HydroSHEDS rivers and basin outlines superimposed over Landsat-ETM+. Note the discrepancy between the CAREERI glacier outlines and the location of the glaciers on the Landsat image.

approximately $2 \mathrm{~km}$. On the other hand, the MODIS lakes and the HydroSHEDS rivers and catchments match the Landsat image quite well.

\subsection{Methods}

\subsubsection{Determining the catchment of a Tibetan lake}

A catchment, also known as drainage basin or watershed, is defined as the area where the surface water from rain and melting snow or ice converges to a single point or outlet, where the water joins another water body such as a lake, river or ocean (DeBarry, 2004). In a closed catchment, also called endorheic basin, surface flow is trapped in a lake or depression without outlet. Water typically leaves the basin by evaporation. As surface water contains some salt that is left behind after evaporation, such sink lakes, e.g. Nam Tso, are typically salty. Figure 4 illustrates the Kekexili catchment. All surface runoff from this closed catchment (described by the purple boundary) converges to Kekexili Lake, a sink lake. Each catchment is surrounded by a geographical barrier, typically a mountain ridge.

Catchments drain into other catchments in a hierarchical pattern, with smaller catchments, also called sub-catchments, combining to larger catchments. Depending on the application scale, a sub-catchment can be determined accordingly. If there is one river that leaves a certain lake with an outlet, that lake is an upstream lake. The sub-catchment for such a lake is part of a bigger catchment. An example for this is the Yinma
Lake catchment. As shown in Fig. 4, the Yinma Lake catchment is a sub-catchment of the Kekexili Lake catchment.

\subsubsection{Determining connections between glaciers and lakes}

Based on the river network, an oriented route of river segments can be determined, running from one node to another. Determining the connection between a glacier and a lake means finding a route from an origin (where the glacier drains into the river network) to the outlet of a lake catchment. In most cases, the origin of the glacier-melt drainage coincides with the from-node of a river segment, as illustrated in Fig. 5. A node of the river network is also used to represent the outlet of a lake catchment, as illustrated in Fig. 6. We describe a connection between lakes as an oriented route from the outlet of a lake catchment to the outlet of another lake catchment. To determine these glacier-lake and lake-lake connections, we have built a module in the ArcGIS environment that executes the four procedures below.

1. Determining which catchment a glacier belongs to. Because of the geographical characteristics of catchment boundaries, each glacier only belongs to one catchment. However, due to discrepancies between the CAREERI glacier outlines and the HydroSHEDS catchments, as shown in Fig. 3, glaciers can seem to belong to more than one catchment. If this is the case, the glacier is assumed to belong to that catchment that contains the largest part of the glacier. For example, 

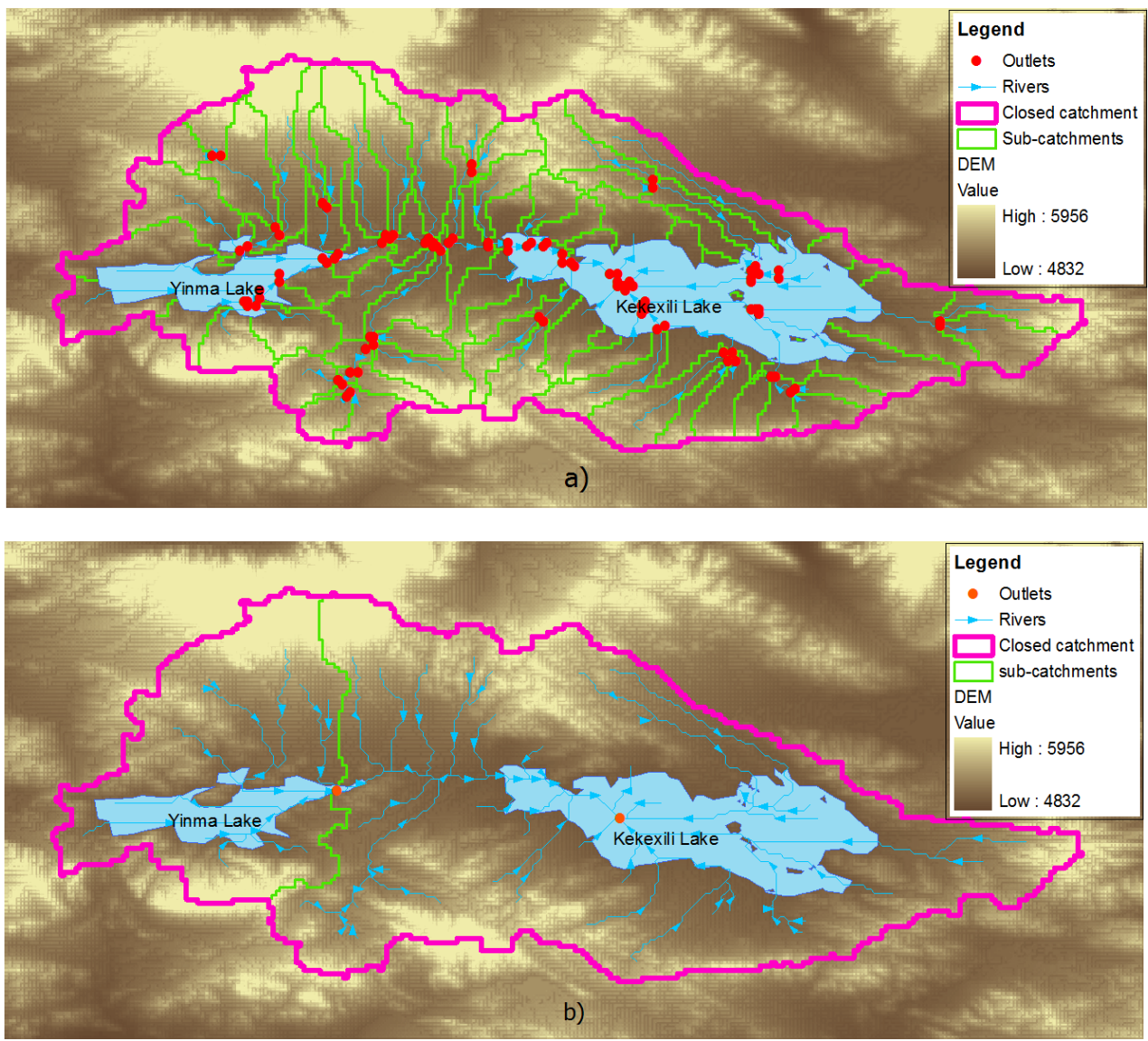

Fig. 4. (a) Catchments represented by at least 100 upstream cells draining into a river segment based on the HydroSHEDS DEM data at 15 arcsecond resolution. (b) The Yinma Lake sub-catchment as part of the Kekexili Lake closed catchment.

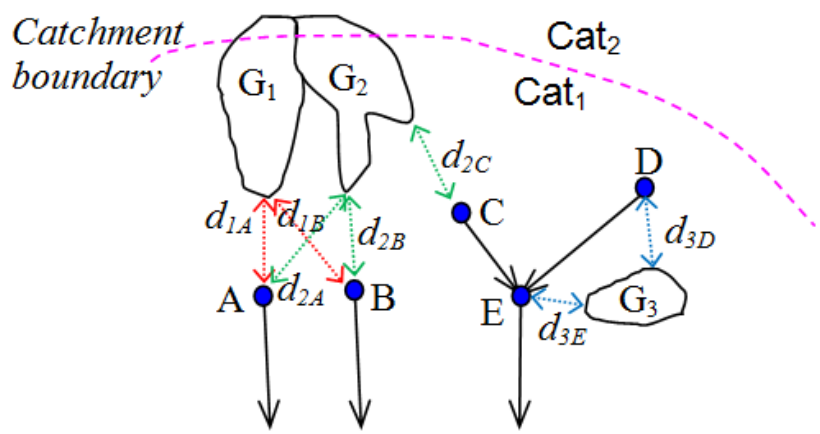

Fig. 5. Glaciers $\mathrm{G}_{1}$ and $\mathrm{G}_{2}$ belonging to catchment Cat 1 and fromnodes $\mathrm{A}, \mathrm{B}$ and $\mathrm{E}$ corresponding to origins of the glacier-melt drainage of glaciers $\mathrm{G}_{1}, \mathrm{G}_{2}$ and $\mathrm{G}_{3}$.

in Fig. 5, the two glaciers $\mathrm{G}_{1}$ and $\mathrm{G}_{2}$ are assumed to belong to catchment $\mathrm{Cat}_{1}$.

2. Estimating the origin of the glacier-melt drainage. In reality, meltwater from a glacier directly drains into the outlet of one catchment, through surface runoff or surface streams. In the glacier mask, each glacier is digitized as an undivided polygon. This means the meltwater from the glacier only drains into the outlet, following one oriented route of river segments. In this study, the source of the route is assumed to be the from-node of that river segment that is nearest to the glacial outline. For each catchment, we compute the distances from each glacier to each from-node, where a distance between a polygon and a point is determined as the minimum distance from the point to a vertex of the polygon. Figure 5 shows the distances from glaciers $G_{1}$ and $G_{2}$ to nodes $A$ and $B$. The from-node with minimum distance to the glacier is considered the source of the drainage route. A distance threshold is used to restrict the number of potential from-nodes. In Fig. 5, the distance from glacier $\mathrm{G}_{1}$ to from-node $\mathrm{A}$ is smaller than the distance to from-node $\mathrm{B}$, so fromnode $A$ is assumed to be the origin of the $G_{1}$ glaciermelt drainage. Similarly, $d_{2 \mathrm{~B}}$ is the smallest distance of $d_{2 \mathrm{~A}}, d_{2 \mathrm{~B}}$, and $d_{2 \mathrm{C}}$, so from-node $\mathrm{B}$ is considered the origin of the $\mathrm{G}_{2}$ glacier-melt drainage, although 


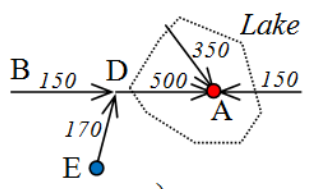

a)

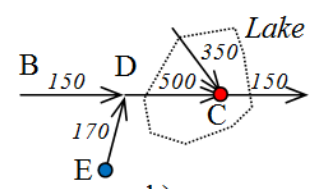

b)

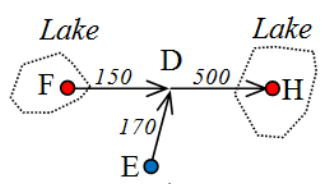

c)

Fig. 6. The sinks $\mathrm{A}$ and $\mathrm{H}$ of closed catchments and the outlets $\mathrm{C}$ and $\mathrm{F}$ of sub-catchments.

in reality glacier $\mathrm{G}_{2}$ may also drain its meltwater via from-node $\mathrm{C}$.

3. Identifying the outlet of a lake catchment. The outlet of each lake has to be inside the lake region. If all incident river segments stream toward the outlet inside a lake, that lake is the sink of a closed catchment. In Fig. $6 \mathrm{a}$ and $\mathrm{c}$, point $\mathrm{A}$ and point $\mathrm{H}$ are the outlets of closed catchments, and are therefore sinks. If even one river segment leaves a lake and drains into another lake or river, the lake is an upstream lake. In Fig. $6 \mathrm{~b}$ and c, point $\mathrm{C}$ and point $\mathrm{F}$ are outlets of their sub-catchments.

4. Indicating the oriented route of river segments from a source to a destination. Each river segment is an oriented vector. At each node of the river network, the number of river segments leaving the node can be zero or one, as illustrated in Fig. 6. Therefore, the oriented route from a source (glacier or lake outlet) to a destination can be determined using the following procedure. First, the river segment whose from-node coincides with the source begins the route. If the to-node of that river segment coincides with the from-node of another river segment, that river segment is added to the route. This process is repeated until the to-node of a river segment coincides with the destination. In Fig. 6a, for example, a route is mapped from source $\mathrm{E}$ to destination $\mathrm{A}$. The route includes two segments (ED and DA), making point D the point of conjunction. Similarly, the route from $\mathrm{F}$ to $\mathrm{H}$ in Fig. $6 \mathrm{c}$ consists of two segments (FD and DH).

The module outputs shapefiles in GIS polyline vector format, with each polyline representing an oriented route from a source to a destination. The route's attributes consist of the identification codes of the source and the destination. The module determines either a connection between a glacier attributed with a glacial code and a lake with a lake code or a connection between two lakes, each with its own lake code. Figure 7 shows the result of the module for the Kekexili catchment.

\subsubsection{Calculating the area of a lake catchment $\left(A_{\mathrm{C}}\right)$}

Based on the HydroSHEDS drainage basin data, we concluded that most of the catchments inside the inner Tibetan Plateau are closed catchments. Lake catchments that are not closed belong to the catchments of one of the major rivers: Brahmaputra, Ganges, Indus, Irrawaddy, Mekong, Salween, Yangtze, or the Yellow River. Because HydroSHEDS only includes the shapes and areas of closed catchments or big river catchments, this study needed to explicitly determine the areas of lake sub-catchments, as follows.

\section{Computing the area of a lake sub-catchment}

The HydroSHEDS river data provides the number of upstream grid cells of each river segment, as illustrated in Fig. 6. From this, the area of each lake catchment can be calculated as the product of grid cell size and total number of upstream grid cells of all river segments converging on the outlet of the lake. For each sub-catchment, the following steps have to be performed.

1. Obtaining the total number of upstream grid cells. For each lake, an outlet is determined by the module described above. Then, the total number of upstream grid cells is determined, by adding up the upstream grid cells derived from river segments draining into the outlet of the lake. In Fig. 6, for example, the total number of upstream grid cells flowing into an outlet is 1000 cells for sink A, 500 cells for sink H, 850 cells for outlet $\mathrm{C}$, and zero for outlet $\mathrm{F}$. In the case of outlet $\mathrm{F}$, the area of the lake catchment was calculated manually using ArcHydro, as mentioned in the discussion section below. For instance, the total number of grid cells representing the Yinma Lake catchment, as illustrated in Fig. 4b, is 3775 .

2. Calculating grid cell size in meters. Grid cell size, including width and height, varies regularly depending on latitude. Grid cell size is approximated using the "haversine" formula (Sinnott, 1984) which takes this dependency into account:

$$
\begin{aligned}
& a=\sin ^{2}(\Delta \text { lat } / 2)+\cos (\text { lat } 1) \cdot \cos (\text { lat } 2) \cdot \sin ^{2}(\Delta \text { lon } / 2) \\
& c=2 \cdot a \tan 2(\sqrt{a}, \sqrt{1-a}) \\
& d=R \cdot c
\end{aligned}
$$

where $d$ is the shortest distance over the Earth's surface, giving an "as-the-crow-flies" distance between two points $\{($ lat1, lon1), (lat2, lon2) $\} . \Delta$ lat, cell height in radians, equals (lat2-lat1) and $\Delta$ lon, cell width in radians, equals (lon2-lon1). $R$ is Earth's mean radius, $6371 \mathrm{~km}$. 


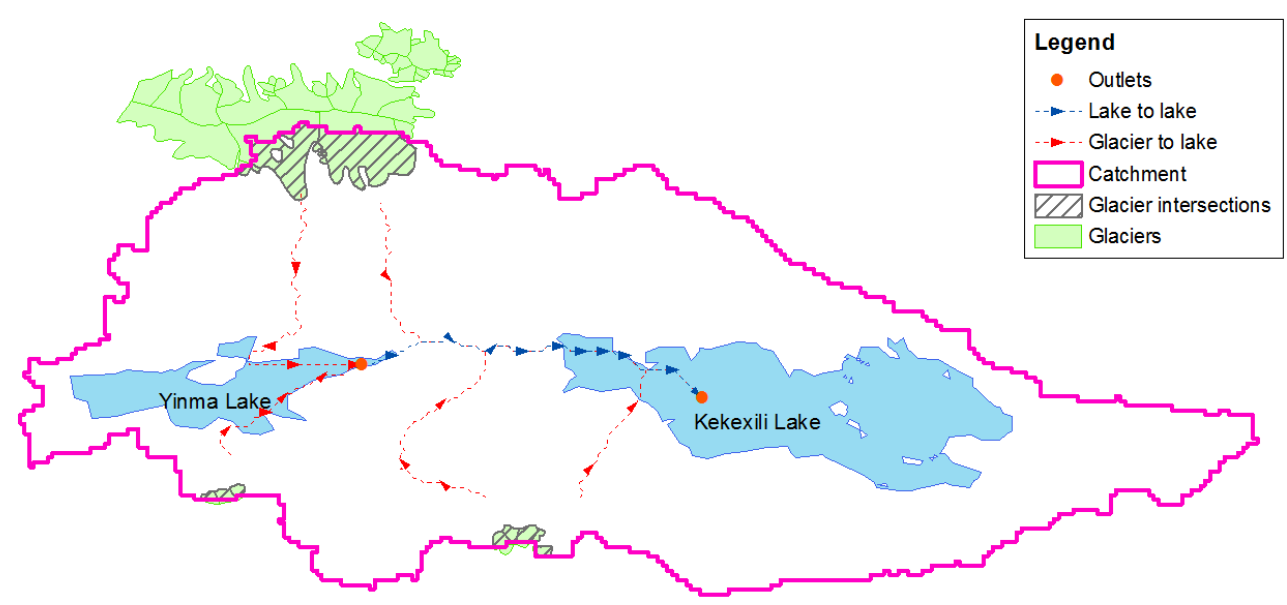

Fig. 7. Determination of the glaciers belonging to the Kekexili catchment, the runoff connections from glaciers to Yinma Lake and Kekexili Lake, and the flow from Yinma Lake to Kekexili Lake.

The Tibetan lake catchments may occupy large areas. The latitude of the outlet of the lake sub-catchment is used to compute grid cell size for the entire lake sub-catchment. For example, the outlet of the Yinma Lake catchment is located at 35.62 degree latitude. Therefore, grid cell size is estimated at $0.3766 \times 0.6433 \mathrm{~km}$. This results in an estimated area of approximately $658.7 \mathrm{~km}^{2}$. Alternatively, the Yinma Lake catchment area can be derived from its geospatial boundary, as illustrated in Fig. 4b. This method also shows the area of the Yinma Lake catchment to be $658.7 \mathrm{~km}^{2}$.

\section{Obtaining the area of a closed lake catchment}

The area of closed Tibetan lake catchments can be determined by three methods.

1. Taken directly from the attributes of the HydroSHEDS drainage basin data. For example, HydroSHEDS reports the Kekexili Lake catchment area as $2636.5 \mathrm{~km}^{2}$.

2. Calculated from grid cell size and total number of upstream grid cells. Similar to the computation of the area of the Yinma Lake sub-catchment above, grid cell size for the Kekexili Lake catchment is $0.3767 \times 0.6433 \mathrm{~km}$. The total number of grid cells in the Kekexili Lake catchment is 15100 . Therefore, the area of the Kekexili Lake catchment is approximately $2635.3 \mathrm{~km}^{2}$.

3. Calculated from its geospatial boundary. The Kekexili Lake catchment occupies an area of $2636.8 \mathrm{~km}^{2}$.

The small differences in area derived from method two are caused by using one representative grid cell size. Bigger catchment areas actually include a range of grid sizes, depending on latitude. For highest accuracy, the rest of the paper derives the area of each closed catchment of a Tibetan lake directly from the drainage basin data.

\subsubsection{Computing the total area of glaciers draining into a lake}

Based on the distribution of the Tibetan glaciers as shown in Fig. 1, it is obvious that part of the glacier meltwater flows to some of the Tibetan lakes. A lake can collect glacier meltwater directly from glaciers or indirectly via upstream lakes. For each lake, we therefore distinguish the total area of directly contributing glaciers $\left(A_{\mathrm{GD}}\right)$ and the total area of upstream glaciers $\left(A_{\mathrm{GU}}\right)$ draining into it.

$A_{\mathrm{GD}}=\sum_{i=1}^{n} A_{i}$

$A_{\mathrm{GU}}=\sum_{i=1}^{n} A_{i}+\sum_{j=1}^{m} A_{\mathrm{GD} j}$,

where $A_{i}$ is the area of the $i$ th glacier directly draining into the lake, and $A_{\mathrm{GD} j}$ is the total area of glaciers contributing directly to the $j$ th upstream lake flowing to the lake.

For example, $41.9 \mathrm{~km}^{2}$ of glaciers drain directly into Yinma Lake and $50.1 \mathrm{~km}^{2}$ into Kekexili Lake, as shown in Fig. 7. Because Yinma Lake is the only lake upstream of Kekexili Lake, the total area of upstream glaciers of Kekexili Lake equals $92 \mathrm{~km}^{2}$.

\subsubsection{Determining the geometric dependency of a lake on glacial runoff}

An indicator for the dependency of a lake on glacier runoff is the ratio between the area in the catchment occupied by glaciers and the lake catchment area itself. If the ratio equals zero, the lake catchment does not contain any glaciers, meaning that the lake is not fed by glaciers at all. If the indicator is close to one, the lake catchment is almost fully covered by glaciers. The indicator $R_{\mathrm{D}}$ indicates the geometric 
Table 1. Tibetan lakes with and without outlet.

\begin{tabular}{llrrrr}
\hline No. & Catchment & $\begin{array}{r}\text { Upstream } \\
\text { lakes }\end{array}$ & $\begin{array}{r}\text { Total surface area of } \\
\text { upstream lakes }\left(\mathrm{km}^{2}\right)\end{array}$ & $\begin{array}{r}\text { Sink } \\
\text { lakes }\end{array}$ & $\begin{array}{r}\text { Total surface area of } \\
\text { sink lakes }\left(\mathrm{km}^{2}\right)\end{array}$ \\
\hline 1 & Brahmaputra & 78 & 1535.3 & 3 & 53.6 \\
2 & Ganges & 14 & 78.5 & 2 & 330.1 \\
3 & Indus & 28 & 1333.5 & 5 & 212.7 \\
4 & Irrawaddy & 0 & 0 & 0 & 0 \\
5 & Mekong & 3 & 15.3 & 1 & 17.7 \\
6 & Salween & 16 & 253.4 & 0 & 0 \\
7 & Yangtze & 87 & 965.4 & 13 & 1157.9 \\
8 & Yellow River & 56 & 2165.6 & 2 & 4170.1 \\
9 & Inner plateau & 323 & 5949.0 & 260 & 20560.7 \\
\hline & Total & 605 & 12296.0 & 286 & 26502.8 \\
\hline
\end{tabular}

dependency of that lake on glaciers draining directly into it. The indicator $R_{\mathrm{U}}$ represents the geometric dependency of the lake on any upstream glaciers.

$$
\begin{aligned}
& R_{\mathrm{D}}=\frac{A_{\mathrm{GD}}}{A_{\mathrm{C}}} \\
& R_{\mathrm{U}}=\frac{A_{\mathrm{GU}}}{A_{\mathrm{C}}}
\end{aligned}
$$

Continuing the above example, $R_{\mathrm{D}}$ for Yinma Lake equals 0.064 , while $R_{\mathrm{D}}$ for Kekexili Lake equals 0.019. Since no glacier-fed lakes drain into Yinma Lake, $R_{\mathrm{U}}$ equals $R_{\mathrm{D}}$ for Yinma Lake. As Yinma Lake is upstream of Kekexili Lake, $R_{\mathrm{U}}$ for Kekexili Lake is 0.035 .

\section{Results}

After defining the geospatial objects and coding the procedures introduced above, we computed $R_{\mathrm{D}}$ and $R_{\mathrm{U}}$, representing the geometric dependency of a Tibetan lake on glaciers, for all the lakes on the Tibetan Plateau with an area over $1 \mathrm{~km}^{2}$. The result shows that 244 Tibetan lakes are directly fed by glaciers while 266 lakes have at least one upstream glacier, possibly buffered by an upstream lake. In addition, we include three case studies, studying the glacial dependency of three lakes: the Aksai Chin Lake in the NorthWestern Kunlun Mountain, the Nam Tso Lake 100 km north of Lhasa and the Yamdrok Lake in the south of Tibet.

\subsection{Lakes with glacial runoff at the Tibetan Plateau}

\subsubsection{Classification of lakes with or without outlet}

The Tibetan Plateau contains 891 lakes over $1 \mathrm{~km}^{2}$, occupying a total area of approximately $38800 \mathrm{~km}^{2} ; 150$ of those lakes have an area of over $50 \mathrm{~km}^{2}$. In Table 1 , the Tibetan lakes are divided into lakes with an outlet (upstream lakes) and without an outlet (sinks). As it turns out, over two-thirds of the Tibetan lake water is contained in sinks. On average, these endorheic lakes are four to five times bigger than lakes with an outlet. In total, there are 96 sinks with an area of over $50 \mathrm{~km}^{2}, 86$ of which are located in the region called the inner plateau.

\subsubsection{Geometric dependency of Tibetan lakes on direct glacier runoff}

Based on the spatial distribution of glaciers and catchments, glacier area per catchment is shown in Table 2. In this paper, we only consider the major catchments of the Tibetan Plateau. According to Table 2, 25.3\% of the total glacier area drains directly into 244 lakes. These lakes consist of 133 upstream lakes and 111 sinks. Thus, $74.7 \%$ of the total glacial area on the Tibetan Plateau directly drains into rivers, notably Brahmaputra, Ganges, Indus, Mekong, Yangtze, and Yellow River. On the inner plateau, $37.4 \%$ of the glacier area drains directly into 160 lakes, mostly situated in the north and the northwest of the inner plateau. Within the Brahmaputra River catchment, $11.1 \%$ of glacier area drains directly into its 33 lakes. The remaining glacier area, approximately $14000 \mathrm{~km}^{2}$, eventually drains into the Brahmaputra River which passes through China, India and Bangladesh. Similarly, $96.6 \%$ of glaciers attributed to the Mekong catchment, approximately $316 \mathrm{~km}^{2}$, eventually drain into the Mekong river, supporting fresh water for China, Myanmar, Laos, Thailand, Cambodia and Vietnam.

Subsequently, we determined $R_{\mathrm{D}}$, the geometric dependency of a lake on direct glacial runoff, for all Tibetan lakes. $R_{\mathrm{D}}$ values are symbolized by red disks in Fig. 8 . We then grouped Tibetan lakes by their $R_{\mathrm{D}}$, as shown in Fig. 9 . Most of the lakes have an $R_{\mathrm{D}}$ below 0.005 , corresponding to $75 \%$ of 244 lakes with at least one glacier draining directly into it. Our calculations also found eight lakes with an $R_{\mathrm{D}}$ over 0.5 . These eight lakes are all relatively small, each occupying approximately $2 \mathrm{~km}^{2}$. They are predictably located near glaciers and spread along mountain ranges in the southern and western Tibetan Plateau. Table 3 shows a list of the 


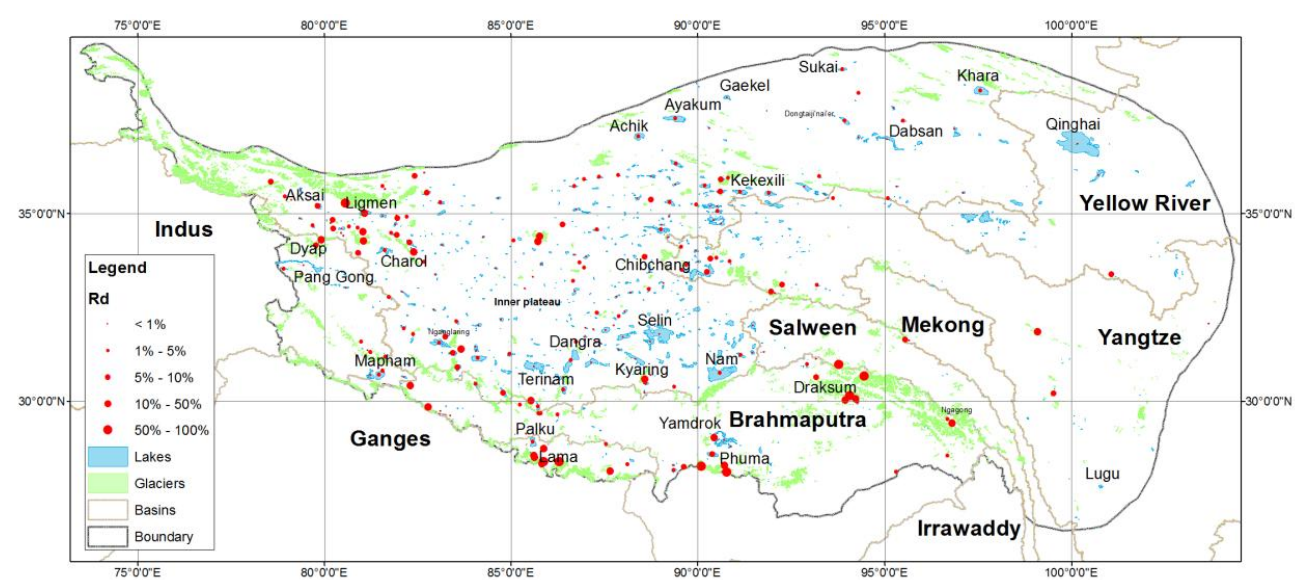

Fig. 8. The geometric dependency of Tibetan lakes on direct glacial runoff $\left(R_{\mathrm{D}}\right)$.

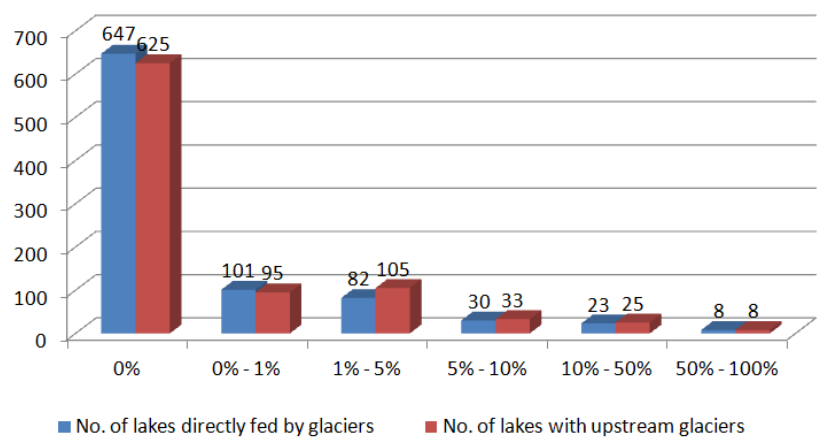

Fig. 9. Tibetan lakes grouped by their level (\%) of geometric dependencies $R_{\mathrm{D}}$ and $R_{\mathrm{U}}$ on glacial runoff.

top ten lakes ranked by total area of directly contributing glaciers.

\subsubsection{Geometric dependency of Tibetan lakes on upstream glaciers}

In addition to being directly fed by glaciers, a Tibetan lake can also be fed indirectly by glaciers, through upstream lakes. That is why we also determined $R_{\mathrm{U}}$ for the 266 lakes, to show the geometric dependency of Tibetan lakes on upstream glaciers. Figure 9 also shows the result of grouping the Tibetan lakes according to their $R_{\mathrm{U}}$. About $75 \%$ of the 266 lakes with at least one upstream glacier correspond have an $R_{\mathrm{U}}$ of under 0.005 . We also found 9 sinks and 13 lakes with runoff that are only indirectly fed by glaciers.

\subsection{Case studies}

The case studies below show the situation in the catchments of three lakes: Aksai Chin Lake, Nam Tso Lake and Yamdrok Lake. The Aksai Chin Lake closed catchment contains a small lake with highest geometric dependency on direct glacial runoff. The geospatial properties of this lake are characteristic for Tibetan lakes with high $R_{\mathrm{D}}$ values. The Nam
Tso Lake closed catchment is included as a case study since it has been a pilot for many studies on lake water level change and water balance. Nam Tso Lake mostly depends on directly contributing glaciers situated in the Nyainqentanglha Mountains. Finally, the Yamdrok Lake sub-catchment is surrounded by snow-capped mountains, but Yamdrok Lake depends much more on indirect glacial runoff via upstream lakes rather than from direct glacial runoff.

\subsubsection{Aksai Chin Lake closed catchment}

Aksai Chin Lake is a sink on the Aksai Chin plateau. The lake is located at $35.208^{\circ} \mathrm{N}, 79.828^{\circ} \mathrm{E}$ in the south of the Kunlun Mountains. The Aksai Chin plateau is a vast high-altitude desert at an average elevation of $5500 \mathrm{~m}$. Aksai Chin Lake is fed by Aksai River and many other streams, as illustrated in Fig. 10. The Aksai Chin Lake closed catchment occupies an area of about $8000 \mathrm{~km}^{2} . A_{\mathrm{GD}}$, the total area of glaciers draining directly into Aksai Chin Lake, equals $673 \mathrm{~km}^{2}$. There is only one small lake upstream of Aksai Chin Lake. $A_{\mathrm{GU}}$, the total area of the glaciers upstream Aksai Chin Lake, is approximately $769 \mathrm{~km}^{2}$. Accordingly, its $R_{\mathrm{D}}$ value is 0.084 while its $R_{\mathrm{U}}$ value is 0.096 . We conclude that the dependency of Aksai Chin Lake on glacial runoff is mostly direct, i.e. almost not tempered by intermediate lakes.

The maximum $R_{\mathrm{D}}$ value we found in this study, 0.816 , belongs to a relatively small lake in Aksai Chin Lake catchment, occupying only $2 \mathrm{~km}^{2}$. It is located at $35.293^{\circ} \mathrm{N}$, $80.572^{\circ} \mathrm{E}$ at an altitude of approximately $5500 \mathrm{~m}$ in the Kunlun Mountains, as shown in Fig. 10. This lake is the only lake draining into Aksai Chin Lake that receives glacial runoff. Its sub-catchment occupies an area of about $118 \mathrm{~km}^{2}$, of which approximately $96 \mathrm{~km}^{2}$ is covered by glaciers. The lake is almost fully fed by glacial meltwater. The geographic properties of this lake are representative for lakes with an $R_{\mathrm{D}}$ value of over 0.5 . 
Table 2. Glacier area per basin on the Tibetan Plateau. $A_{\text {Total }}$ is the total area of glaciers with direct runoff into a lake and $R_{\text {Total }}$ is the ratio between $A_{\text {Total }}$ and the total glacier area.

\begin{tabular}{llrrrrr}
\hline No. & Basin name & $\begin{array}{r}\text { Basin area } \\
\left(\mathrm{km}^{2}\right)\end{array}$ & $\begin{array}{r}\text { Total glacier } \\
\text { area }\left(\mathrm{km}^{2}\right)\end{array}$ & $\begin{array}{r}\text { No. of directly } \\
\text { glacier-fed lakes }\end{array}$ & $\begin{array}{r}A_{\text {Total }} \\
\left(\mathrm{km}^{2}\right)\end{array}$ & $\begin{array}{r}R_{\text {Total }} \\
(\%)\end{array}$ \\
\hline 1 & Brahmaputra & 344528 & 15677 & 33 & 1748.2 & 11.1 \\
2 & Ganges & 39772 & 3636 & 10 & 355.5 & 9.8 \\
3 & Indus & 101428 & 2430 & 14 & 727.9 & 30.0 \\
4 & Irrawaddy & 4227 & 32 & 0 & 0.0 & 0.0 \\
5 & Mekong & 86392 & 327 & 2 & 11.0 & 3.4 \\
6 & Salween & 108266 & 1893 & 4 & 53.4 & 2.8 \\
7 & Yangtze & 484317 & 2432 & 18 & 520.0 & 21.4 \\
8 & Yellow River & 263928 & 297 & 3 & 167.1 & 56.4 \\
9 & Inner plateau & 1098382 & 26512 & 160 & 9909.7 & 37.4 \\
\hline & Total & 2531240 & 53236 & 244 & 13492.8 & 25.3 \\
\hline
\end{tabular}

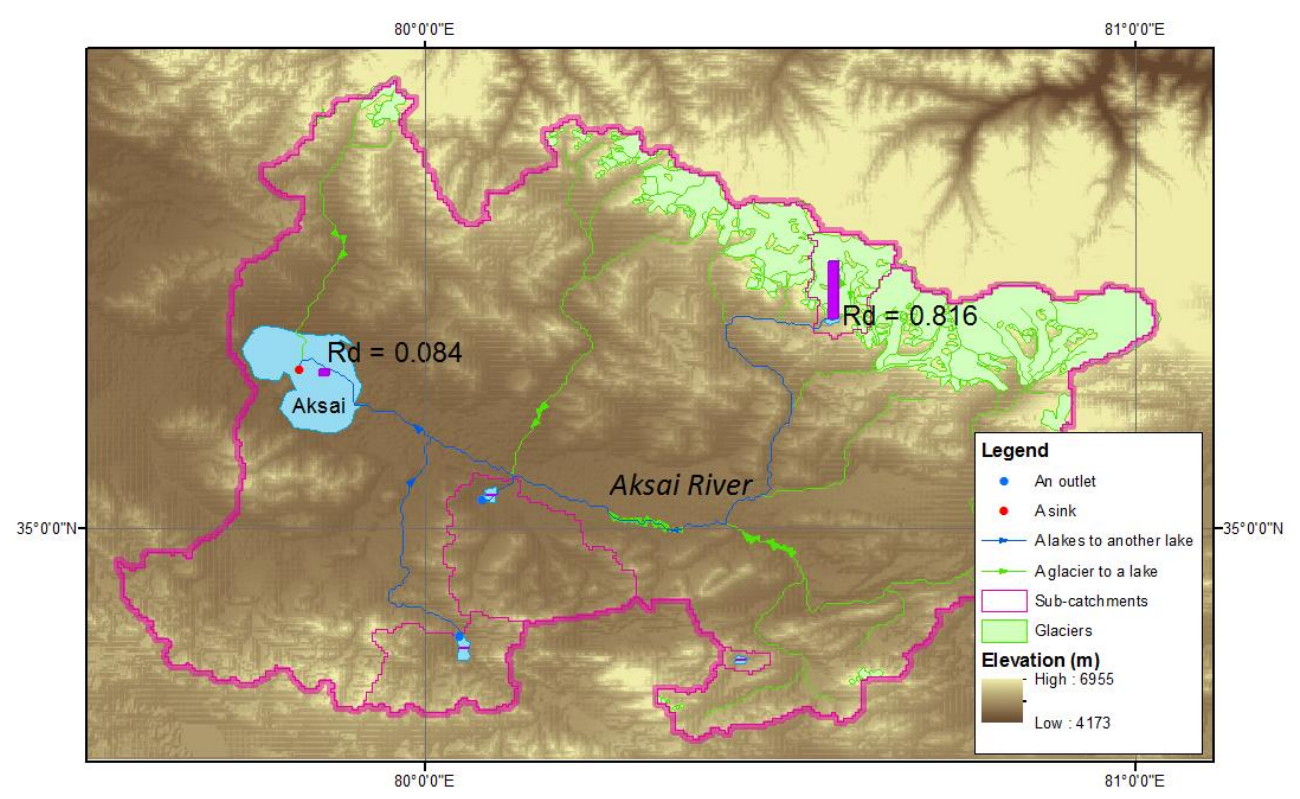

Fig. 10. The maximum $R_{\mathrm{D}}$ value occurs at a small lake belonging to the Aksai Chin Lake closed catchment.

\subsubsection{Nam Tso closed catchment}

Nam Tso Lake, also called Nam Tso or Nam Co, is the largest salt lake on the Tibetan Plateau. The lake is located at $30.718^{\circ} \mathrm{N}, 90.646^{\circ} \mathrm{E}$ at an elevation of $4718 \mathrm{~m}$ and occupies a surface area of about $1960 \mathrm{~km}^{2}$. Nam Tso is a sink at the foot of the Nyainqentanglha Mountains and is mostly fed by glaciers from these mountains. While Nam Tso has two small upstream lakes, no glacier drains into these smaller lakes. The Nam Tso closed catchment occupies an area of $10741 \mathrm{~km}^{2}$, as shown in Fig. 11 while the total area of direct glaciers draining into Nam Tso is calculated as $334.5 \mathrm{~km}^{2}$. This makes it one of the top ten lakes directly fed by glaciers, as shown in Table 3. This gives it an $R_{\mathrm{D}}$ value of 0.031 , which indicates that over $3 \%$ of the Nam Tso catchment is covered by glaciers. This $R_{\mathrm{D}}$ value can be considered relatively high, and shows a relatively high dependency of Nam Tso on glacial runoff.

According to Krause et al. (2010), the sum of all water inflow to Nam Tso Lake resulted in an increase of the lake volume by $33.5 \mathrm{~km}^{3}$ for the period between November 1961 and October 2010. This study computed the mean total annual inflow of water from glaciers into Nam Tso as $7.12 \mathrm{~km}^{3} \mathrm{yr}^{-1}$ during the observed period, and indicated that this glacial meltwater is the largest contributor to the increased lake water volume. This was corroborated by analysis of satellite laser altimetry data from between 2003 and 2009, which show that Nam Tso has a positive lake level trend of $+23 \mathrm{~cm} \mathrm{yr}^{-1}$ (Phan et al., 2012a) or $+25 \mathrm{~cm} \mathrm{yr}^{-1}$ (Zhang et al., 2011). At the same time, Bolch et al. (2010) 
Table 3. Top ten lakes with the largest total area of directly contributing glaciers. $A_{\mathrm{C}}$ is the area of the lake catchment, $A_{\mathrm{GD}}$ is the total area of glaciers directly draining into the lake, and $R_{\mathrm{D}}$ is the geometric dependency of the lake on direct glacial runoff.

\begin{tabular}{|c|c|c|c|c|c|c|c|}
\hline No. & Lake name & Latitude & Longitude & $\begin{array}{r}\text { Lake area } \\
\left(\mathrm{km}^{2}\right)\end{array}$ & $\begin{array}{r}A_{\mathrm{C}} \\
\left(\mathrm{km}^{2}\right)\end{array}$ & $\begin{array}{r}A_{\mathrm{GD}} \\
\left(\mathrm{km}^{2}\right)\end{array}$ & $R_{\mathrm{D}}$ \\
\hline 1 & Dongtaiji'nai'er Lake & 37.496 & 93.935 & 223 & 34148 & 691.5 & 0.020 \\
\hline 2 & Aksai Chin Kul & 35.208 & 79.828 & 166 & 7993 & 672.8 & 0.084 \\
\hline 3 & Ligmen Tso & 35.028 & 81.082 & 249 & 2727 & 518.7 & 0.190 \\
\hline 4 & Ngagong Tso & 29.413 & 96.817 & 9 & 1290 & 484.6 & 0.376 \\
\hline 5 & Ayakum Kul & 37.546 & 89.373 & 631 & 24147 & 383.7 & 0.016 \\
\hline 6 & Nam Tso & 30.718 & 90.646 & 1967 & 10741 & 334.5 & 0.031 \\
\hline 7 & Draksum Tso & 30.026 & 93.997 & 26 & 1722 & 307.2 & 0.178 \\
\hline 8 & Nganglaring Tso & 31.540 & 83.101 & 500 & 12464 & 291.2 & 0.023 \\
\hline 9 & Achik Kul & 37.067 & 88.431 & 355 & 13263 & 280.8 & 0.021 \\
\hline 10 & Dabsan Nor & 36.978 & 95.205 & 294 & 109629 & 242.7 & 0.002 \\
\hline
\end{tabular}

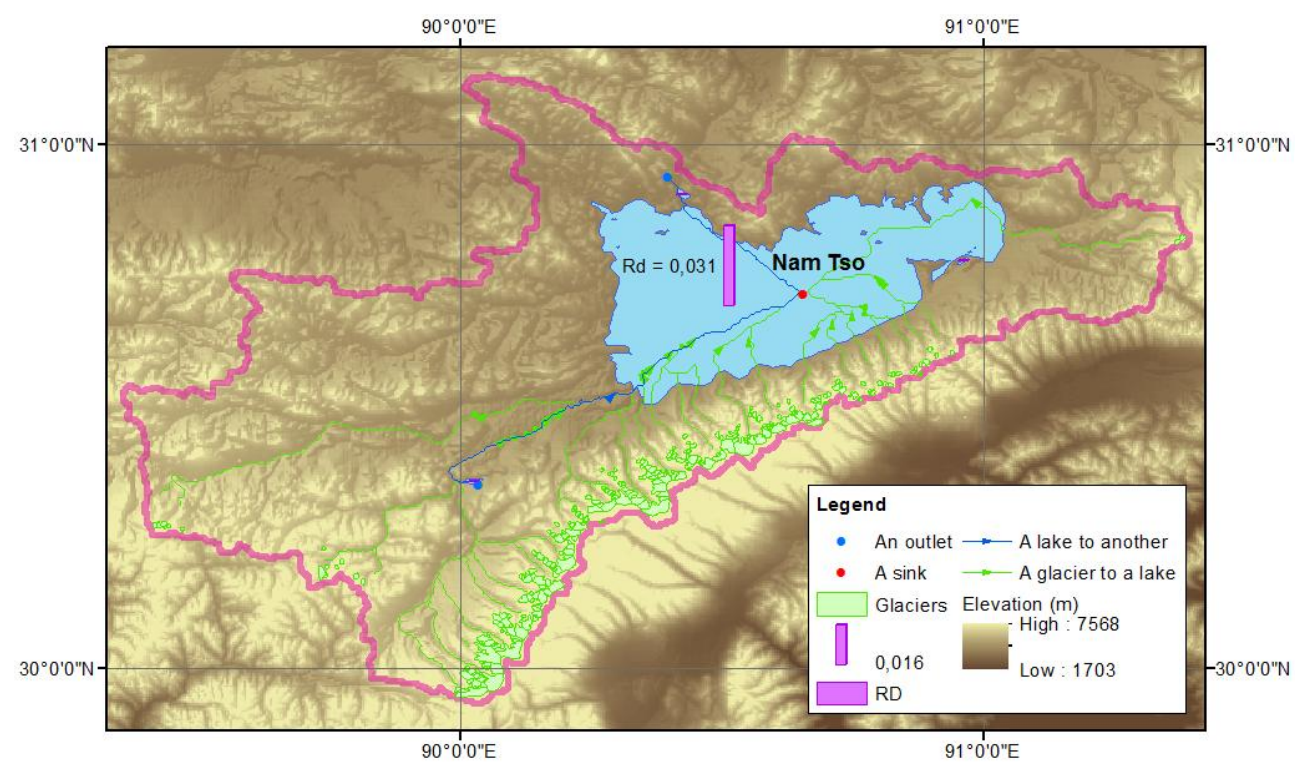

Fig. 11. Geometric dependency of Nam Tso Lake on glacial runoff.

reported that the glaciers from the Nyainqentanglha Mountains draining into the Nam Tso catchment were shrinking during the period 2001-2009, based on analysis of optical data from Hexagon KH-9 and Landsat MSS (both 1976), Metric Camera (1984), and Landsat TM/ETM+ (1991, 2001, 2005, 2009).

Nam Tso is exceptional among the many lakes on the Tibetan Plateau because it is relatively well studied. In our opinion, our analysis of Nam Tso indicates the potential of the approach of this paper. By correlating the geometric dependency of Nam Tso Lake on glacial runoff to other papers on water level, we can link glacial shrinkage and lake level increase. The possible significance of these links should be studied further for a large number of lakes.

\subsubsection{Yamdrok Lake sub-catchment}

Yamdrok Lake, also called Yamzho Yumco, is one of the largest lakes on the Tibetan Plateau. The lake is fan-shaped and occupies an area of about $640 \mathrm{~km}^{2}$. It is located at $28.979^{\circ} \mathrm{N}, 90.717^{\circ} \mathrm{E}$ at an elevation of about $4440 \mathrm{~m}$ on the north side of Mt. Qomolangma. The lake is fed by numerous small streams. The outlet stream of the Yamdrok Lake sub-catchment is at the far western end of the lake, as shown in Fig. 12. The Yamdrok Lake sub-catchment, derived from the HydroSHEDS drainage basin data, occupies an area of $9940 \mathrm{~km}^{2}$ and belongs to the major catchment of Brahmaputra River. Although surrounded by many snow-capped mountains, Yamdrok Lake is only directly fed by a few glaciers occupying a total area of only $21 \mathrm{~km}^{2}$. Therefore, Yamdrok Lake's $R_{\mathrm{D}}$ only equals 0.002 . The total area of glaciers upstream of Yamdrok Lake, however, is $255 \mathrm{~km}^{2}$, and this gives 


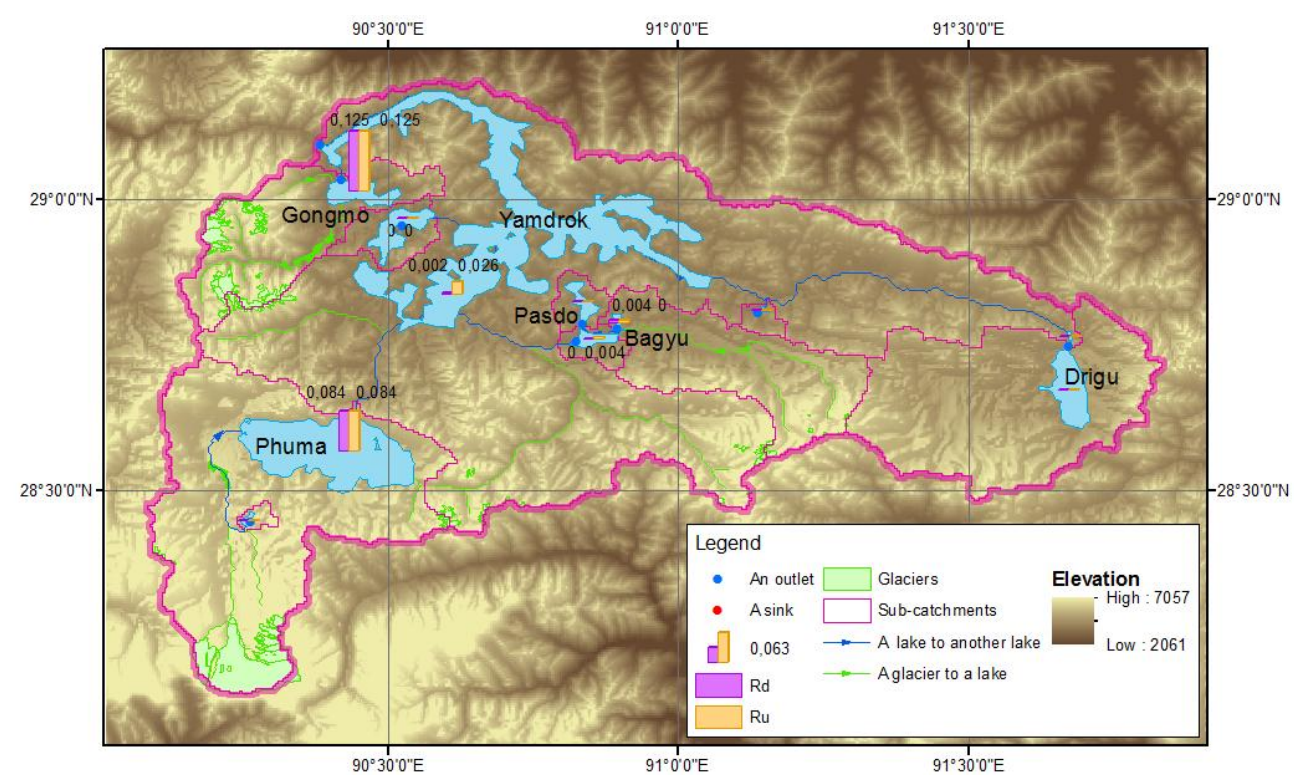

Fig. 12. Geometric dependency of Yamdrok Lake sub-catchment lakes on glacial runoff.

Yamdrok Lake a relatively high $R_{\mathrm{U}}$ of 0.026 . This means that Yamdrok Lake depends more on glacial runoff from upstream lakes than on direct glacial runoff.

The geometric links also indicate that three nearby lakes, Bagyu, Gongmo and Phuma, flow into Yamdrok Lake, as shown in Fig. 12. Although no glacier directly feeds it, Bagyu Lake depends on glacial runoff through a nearby small lake with an $R_{\mathrm{D}}$ of 0.004 , giving Bagyu Lake an $R_{\mathrm{U}}$ of 0.004 . Yamdrok Lake has a high dependency on glacial runoff from Gongma Lake and Phuma Lake.

Gongmo Lake is another of the lakes upstream of Yamdrok Lake. The lake occupies an area of about $40 \mathrm{~km}^{2}$. It is located near the western end of Yamdrok Lake, at an altitude of $4500 \mathrm{~m}$. The Gongmo Lake sub-catchment occupies an area of $620 \mathrm{~km}^{2}$, with $77.7 \mathrm{~km}^{2}$ of the area covered by glaciers. Therefore, the dependency of Gongmo Lake on direct glaciers is high, with an $R_{\mathrm{D}}$ value of 0.125 .

Phuma Lake, also called Puma Yumco, is a big upstream lake draining into Yamdrok Lake, as shown in Fig. 12. Phuma Lake occupies an area of about $285 \mathrm{~km}^{2}$, at an elevation of $5030 \mathrm{~m}$. The lake is directly fed by meltwater from surrounding mountains. The area of the Phuma Lake sub-catchment equals about $1815 \mathrm{~km}^{2}$. Our analysis indicates that the total area of glaciers draining directly into Phuma Lake is about $153 \mathrm{~km}^{2}$, indicating Phuma Lake also depends highly on direct glacial runoff, corresponding to an $R_{\mathrm{D}}$ value of 0.084 .

\section{Discussion}

In this discussion chapter, two topics are considered. First, we discuss how the geometric links we quantified between glaciers and lakes are expected to contribute to further understanding of the hydrological mass balance of the Tibetan Plateau. The second part gives more details on several technical aspects, such as input data, computation times and the non-standard processing steps that were necessary to arrive at the results presented above.

\subsection{The hydrological interpretation of geometric dependency on glacial runoff}

Because of the high relief of the Tibetan Plateau, elevation dominates the hydrological processes that influence mass balance. This high relief also makes it more difficult to assess the state of mass balance from remote sensing data, when compared to monitoring the mass balance of the relatively flat Greenland and Antarctica ice sheets (Radic and Hock, 2011). Recent work, however, showed two things: how to gather information on water level variations for many Tibetan lakes (Zhang et al., 2011; Phan et al., 2012a), and how to collect data on glacier mass changes on the borders of the Tibetan Plateau (Kaab et al., 2012). It was also shown that lake levels vary per season and per location (Phan et al., 2012b), in a way that is not directly understandable without further information. State-of-the-art modeling results of the hydrological mass balance of the Tibetan Plateau relies on an underlying grid of surface runoff with a grid size in the order of $5 \mathrm{~km}$ (Immerzeel et al., 2010).

The first goal in establishing and quantifying geometric links between glaciers and lakes is to obtain direct insight into the dependency of the different lakes on direct and indirect glacial runoff. Although glaciers may also lose mass due to sublimation and evaporation, a major part of the mass loss is due to melting. This meltwater will drain away via streams that may end in one of the $\sim 900$ Tibetan lakes. Groundwater 


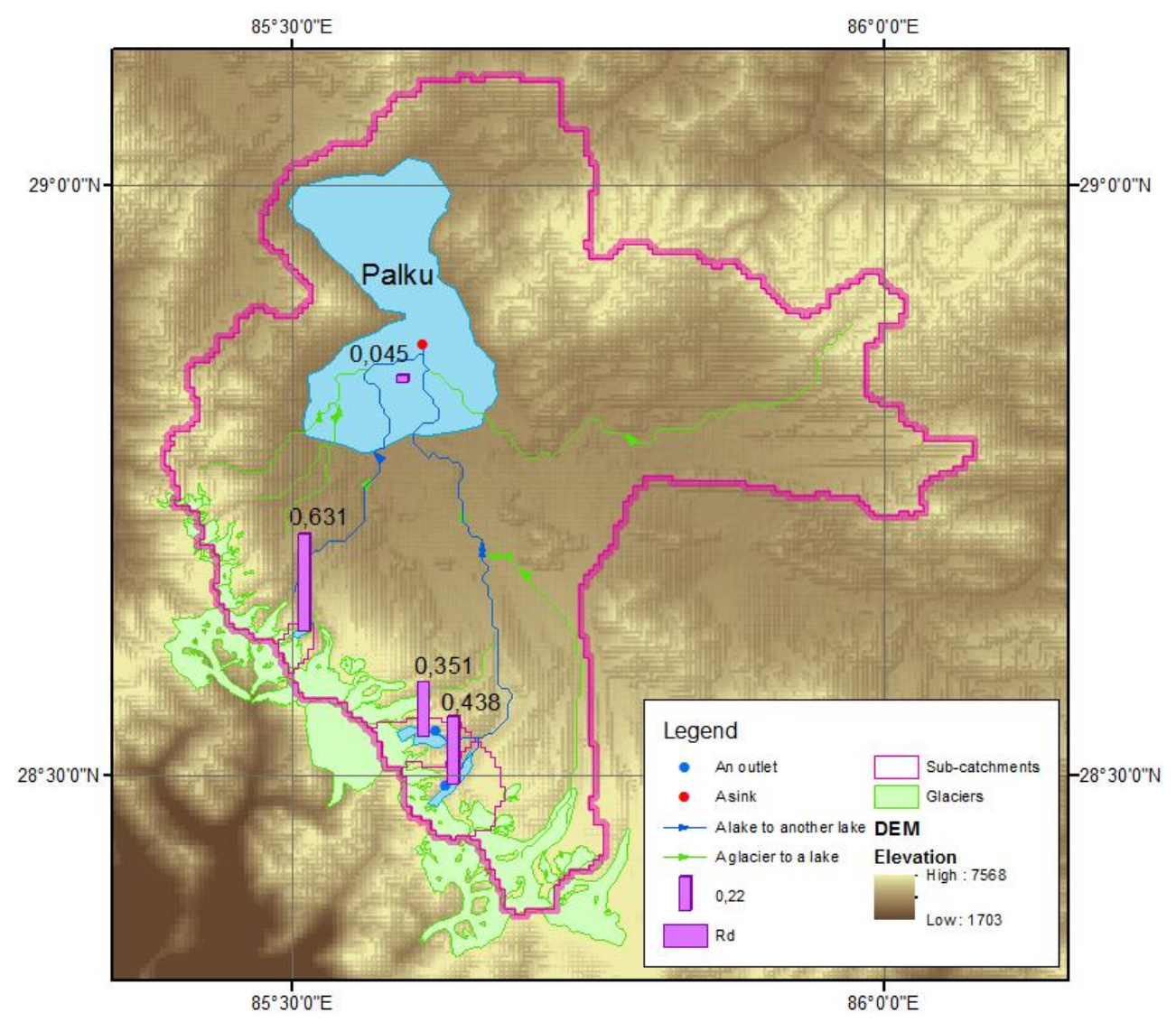

Fig. 13. The lake sub-catchments, belonging to the Palku Lake closed catchment, are manually created using ArcHydro.

flow on the Tibetan Plateau is also largely determined by elevation differences, and a large part of the groundwater flow will also end up in lakes. Estimating discharge due to melting has already successfully been attempted at smaller scale. Krause et al. (2010), for example, used a degree day factor approach to estimate the mean total annual inflow of glacier meltwater into the Nam Tso Lake at $7.12 \mathrm{~km}^{3} \mathrm{yr}^{-1}$ during the period between 1961 and 2010. Similarly, Zhou et al. (2010) also used a degree day model to study how changes in air temperature and precipitation from 2007 to 2008 affected glacier runoff from Zhadang glacier runoff in the Nam Tso Lake basin. To quantify each lake's potential inflow of glacial meltwater, we determine the $R_{\mathrm{D}}$ (geometric dependency of a lake on direct glacial inflow). Clearly, glaciers buffered by an upstream lake may also have impact on a downstream lake's water balance, but only in an indirect way. Therefore, we distinguish between direct and indirect inflow by determining a separate $R_{\mathrm{U}}$ value (geometric dependency of a lake on both direct and indirect glacial inflow). Further research is expected to show to what extent the difference in dependency on glacial meltwater can explain differences in lake level variations.

A second goal of the work in this paper is to facilitate and further constrain future hydrological modeling efforts. This work shows in detail how to create a surface runoff grid for the Tibetan Plateau, including lakes, rivers and glaciers, at a resolution of an unprecedented $\sim 400 \mathrm{~m}$. Combining this hydrological model with existing and new empirical results on the mass balance of lakes and glaciers is expected to result in new and more accurate hydrological mass balance predictions.

\subsection{Details on computing the geometric dependency of lakes on glacial runoff}

\subsubsection{Sensitivity of the results}

In this paragraph, we discuss how the results presented in this paper depend on the quality of the different data sets and on the processing.

\section{The MODIS land-water mask}

The MODIS MOD44W $250 \mathrm{~m}$ land-water mask was produced using over $8 \mathrm{yr}$ of Terra MODIS spectral data, over $6 \mathrm{yr}$ of Aqua MODIS spectral data and Shuttle Radar Topography Mission (SRTM) elevation data (GLCF, 2012). With a pixel size of $250 \mathrm{~m}$, the spatial resolution of the MODIS landwater mask is relatively low. Besides, the mask also contains 


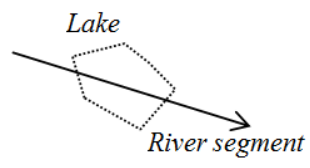

a)

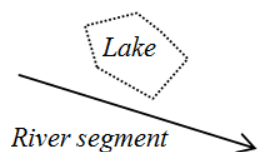

b)

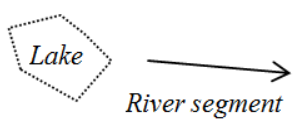

c)

Fig. 14. Description of the low resolution of the HydroSHEDS rivers superimposed over the MODIS lakes.

errors affecting the shape of the lake polygons. For example, there are cases where two different lake polygons represent the same lake, e.g. Yamdrok Tso or Pang Gong Tso, and, vice versa, where different lakes are included in one lake polygon, e.g. Chibchang Tso and Mitijiangzhanmu Tso. Except for permanent lakes, the MODIS land-water mask also contains some small seasonal lakes. In addition, the mask contains many small polygons representing parts of rivers.

The Tibetan lake layer, used in this paper, was derived from the MODIS land-water mask. It is stored in shapefile format and is the product of a previous study (Phan et al., 2012a). All lake outlines were checked and river remains were removed with the support of Google Earth and one set of Landsat TM data. The Landsat TM image data used as reference was acquired in 2002 and 2003 which corresponds to the acquisition of the data used for the MODIS land-water mask. We believe that the number of remaining errors in the lake mask is quite small, also because most elevations considered now are already unambiguously representing a lake surface of a known lake, compare also Phan et al. (2012a).

\section{The HydroSHEDS river data derived from SRTM}

SRTM data are used to generate the HydroSHEDS data sets at 3 arc second resolution (approximately $90 \mathrm{~m}$ at equator). With a pixel size of $\sim 90 \mathrm{~m}$, the SRTM data represent a digital topographic map of the Earth's land surface. Note that at $90 \mathrm{~m}$ resolution it is possible that some river channels running in for example, a canyon, are not well represented. This may in some cases result in incorrect channel representations in derived products, such as the HydroSHEDS product. The SRTM data has an absolute horizontal accuracy of below $20 \mathrm{~m}$ and a relative vertical accuracy of less than $10 \mathrm{~m}$ (Bamler, 1999; Zandbergen, 2008). The HydroSHEDS data sets including stream networks, watershed boundaries, drainage directions and ancillary data layers such as flow accumulations, distances and river topology information are derived from SRTM DEM, basically using an eight-direction (D8) flow model (O'Callaghan and Mark, 1984). The D8 method estimates surface flow in gridded digital terrain models by systematically tracking 8 possible directions from a candidate pixel to one of its eight neighbors. This method works well when the direction of steepest descent is welldefined. Errors in the elevation data and lack of relief may therefore result in wrong channel locations, or even in locally wrong flow directions. The level of detail of these hydrologic data sets depends on the minimum number of accumulation upstream pixels that is used to create a stream or a river segment.

Based on the river network and the location of a lake, the outlet of each lake catchment is defined as a point inside the lake region. If river segments all stream to the intersection point inside the lake polygon, the lake has no outflow. The intersection point is considered a sink of a closed catchment. If one river segment has the from-node inside and the tonode outside a lake, the lake has an outflow. The from-node of the river segment is considered the outlet of a lake subcatchment. By applying this rule, we could identify the outlets of most of the 891 Tibetan lakes. The outlets of some lakes are not automatically determined due to the low resolution of the river network, as described in Fig. 14. These lakes were marked and checked manually. If glaciers occur in the lake's catchment, we manually created a detailed drainage network of the lake's area in ArcHydro, as described in the Sect. 4.2.2.

The low resolution of SRTM has for example affected the connection between Chibchang Tso Lake and Mitijiangzhanmu Tso Lake (Appendix). In reality, these lakes are connected by a small channel, as shown in Fig. 15. However, the HydroSHEDS catchment data, derived from SRTM, represent Chibchang Tso Lake and Mitijiangzhanmu Tso Lake as sinks in two separate closed catchments. The mean altitude of Mitijiangzhanmu Tso is $4938.1 \mathrm{~m}$ while the mean altitude of Chibchang Tso is $4933.4 \mathrm{~m}$, according to SRTM. It is quite possible that in reality these two lakes connect to a lake during part of the year. It should be further investigated.

\section{The flat outlets}

Also the height differences between linked lakes have been evaluated to further identify possible suspicious cases. In total, there are 311 pairs of linked lakes. For 16 pairs, the difference in mean elevation is only below $1 \mathrm{~m}$. They all represent connections between two nearby lakes inside the same closed catchment. Besides, the mean elevation of a lake is also affected by the lake shape. For example, at the Jagok Tso Lake catchment, Chagut Tso at a mean attitude of $4558.6 \mathrm{~m}$ directly drains into Jagok Tso at a mean altitude of $4557.2 \mathrm{~m}$ and Kyaring Tso at a mean altitude of $4656.0 \mathrm{~m}$ directly drains into Chikut Tso at a mean attitude of $4654.6 \mathrm{~m}$ before draining into Jagok Tso (Appendix). 


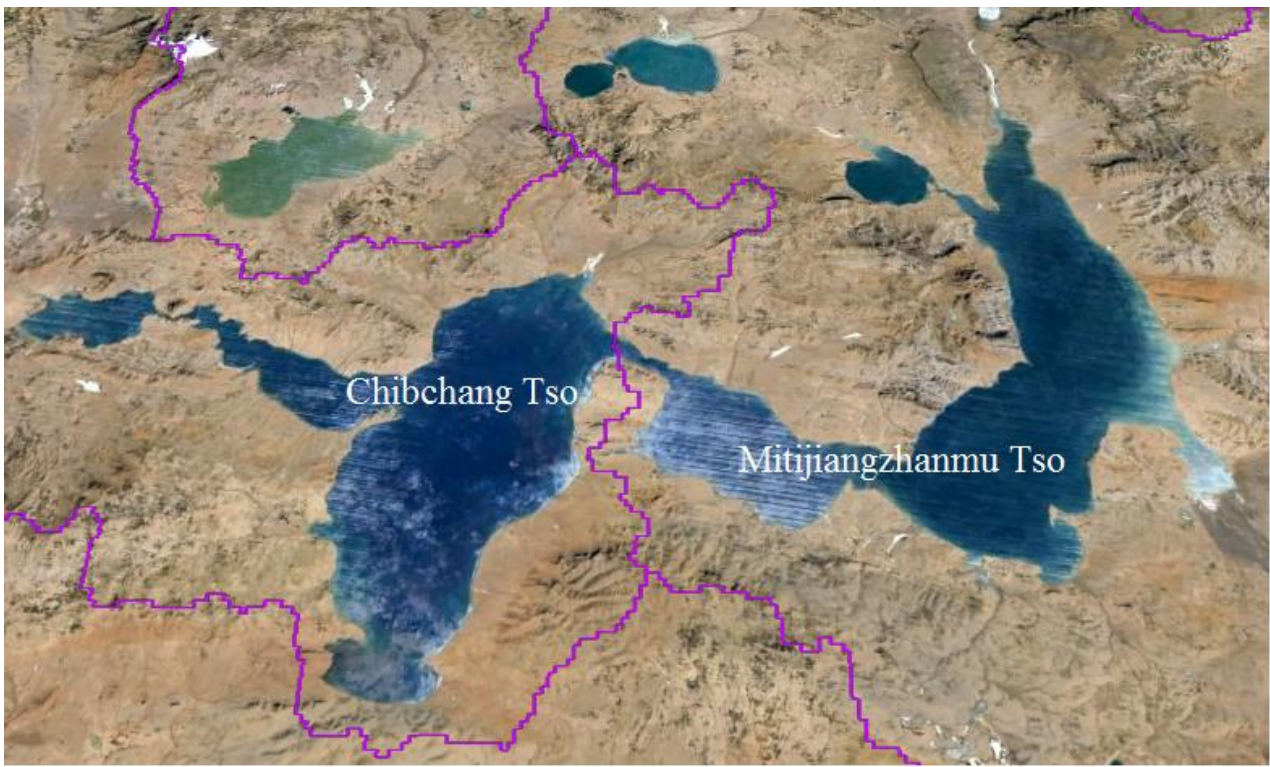

Fig. 15. Effect of the low resolution of SRTM in the separation of Chibchang Tso and Mitijiangzhanmu Tso into two closed catchments derived from the HydoSHEDS drainage basins when overlaid on Google Earth.

The HydroSHEDS river network is susceptible to various errors, foremost in flat regions, including lake surfaces. In fact, river segments inside a lake polygon are still oriented. This can affect the location of the outlet of a lake. Furthermore, the vertical error of SRTM can influence the orientation of a river segment. Of the 311 pairs, there are 99 in which the difference in mean elevation between two linked lakes is less than $20 \mathrm{~m}$. It is noticed that 33 of such 99 pairs are directly dominated by glaciers. Thus, if some of the links orient inversely by the elevation error, the corresponding indicator values $\left(R_{\mathrm{U}}\right)$ of geometric dependency of the linked lakes are affected.

\section{The seasonal variations}

In this paper, we use the Tibetan lake layer, as produced for a previous study in which Phan et al. (2012a) removed small seasonal lakes or empty depressions from the MODIS landwater mask. However, as a result of the drainage network analysis, we also found 140 sinks without permanent lake, according to the MODIS land-water mask. Most of them are in the northern Tibetan Plateau. It is possible that these sinks correspond to seasonal lakes that may be empty in winter and with water in summer by rainfall and snow melt.

\section{The deformations in the glacier mask}

Recent studies report that the total glacier area on the Tibetan Plateau is shrinking. This affects the indicator values $R_{\mathrm{D}}$ and $R_{\mathrm{U}}$ because the total area of glaciers directly and indirectly draining into a lake changes. In this paper, the area of each glacier, derived from the CAREERI glacier mask, is determined based on both remote sensing and in situ data from 1978 to 2002 . Thus, the indicator values $R_{\mathrm{D}}$ and $R_{\mathrm{U}}$ represent the geometric dependency of the Tibetan lakes on glacial runoff in 2002. Therefore, in order to determine the indicator values $R_{\mathrm{D}}$ and $R_{\mathrm{U}}$ in later years, the rates of retreat in glaciers can be used to re-compute the area of each glacier. These rates are reported in recent literatures for individual regions on the Tibetan Plateau. For example, Wang et al. (2011) estimated a retreat in glacier area of $21.7 \%$ in the Middle Qilian Mountain region from 1956 to 2003. Thus, the area of each glacier in this region can decline $4.6 \%$ in 2012. Subsequently, the indicator values $R_{\mathrm{D}}$ and $R_{\mathrm{U}}$ at the lakes dominated by glaciers in this region have a reduction of $4.6 \%$ in 2012 as well.

\subsubsection{Manually calculating the area of lake sub-catchments using ArcHydro}

As mentioned in Sect. 2.2.3, the area of a lake sub-catchment is the product of its grid cell size and the total number of grid cells draining into its outlet. Due to the limited resolution of the HydroSHEDS river network, the outlet of a lake sub-catchment can be just one of several sources of a river network, e.g. outlet F in Fig. 6c. In this particular case, the total number of grid cells cannot be determined automatically from the HydroSHEDS data. However, the area of a lake sub-catchment can also be calculated based on its geometric shape. The ArcHydro extension of ArcGIS supports manual outlining of catchments from a digital elevation model.

Based on the HydroSHEDS DEM data at 15 arcsecond resolution (USGS, 2012), lake sub-catchments were outlined manually using the ArcHydro tools for these cases. We found 
19 such lakes directly fed by glaciers. First, we clipped the terrain data for the 19 lake regions from the HydroSHEDS DEM. Second, we created small catchments by following the ArcHydro user guide. For this purpose, a threshold of 30 upstream drainage grid cells is used to define a river segment, to improve the level of detail of the river network. This threshold also means that this manual outlining will only produce catchments with an area of at least 30 grid cells. Subsequently, for each lake, we determined the lake sub-catchment by merging the small catchments draining into its outlet, as illustrated in Fig. 4. Finally, the catchment area was obtained directly from its geometric shape. As an example, the geometric shapes of the three small lake sub-catchments in the south of the Palku Lake basin are shown in Fig. 13.

\subsubsection{Dividing the Tibetan Plateau into parts for speeding up computations}

The Tibetan Plateau is large, so it takes a long time to run the drainage network analysis module and determine connections between glaciers and lakes. When the module was run on a desktop with a $3.2 \mathrm{GHz} \mathrm{CPU}$ and $2 \mathrm{~GB}$ RAM or on a laptop with a $2.2 \mathrm{GHz}$ Core 2 Duo CPU and 4 GB RAM, it took 4 or 5 days to process the data for the whole Tibetan Plateau. Sometimes the process stopped altogether. Although the river network is organized per catchment, a large amount of PC memory is required to find a route of river segments for each glacier. This holds especially for the major catchment of Brahmaputra River, which occupies a large area and has a densely spread river network. To complicate calculations, most of the glaciers inside the Brahmaputra major catchment do not drain into the outlet of any lake catchment. To more efficiently calculate the total area of directly contributing glaciers draining into each lake on the whole plateau, we divided the plateau into sub-areas, grouping some closed catchments on the inner plateau. As a consequence, we had to run the module several times to manually determine connections between glaciers and lakes. In addition, for each major river catchment we created several virtual outlets in the river network to reduce computation time. Then we used the module to make connections between the virtual outlets, the way it is also used to make connections between lakes. Finally, we found the connections between glaciers and lakes in each major catchment by combining routes from glaciers to outlets and between outlets.

\section{Conclusions}

In this paper, we calculate for each lake larger than $1 \mathrm{~km}^{2}$ on the Tibetan Plateau (891 in total) how much it is geometrically dependent on glacial runoff. The results show that 244 of these lakes receive direct runoff from glaciers while another 22 lakes only obtain glacial meltwater buffered by upstream lakes. The ratio between the total area of glaciers draining into a lake and the area of its catchment $\left(R_{\mathrm{D}}\right)$ represents the dependency of a lake on glacial runoff. Geometric connections between glaciers and lakes are determined based on drainage network analysis. From this, the total area of directly contributing glaciers or the total area of upstream glaciers draining into a lake is computed. This geometric dependency is a first proxy for the actual dependency of a lake on glacial runoff. Our results clearly list which lakes are more or less dependent on glacial runoff and therefore indicate which lakes are expected to be strongly affected by the predicted further shrinkage of the glaciers on the Tibetan Plateau.

\section{Supplementary material related to this article is available online at http://www.hydrol-earth-syst-sci.net/ 17/4061/2013/hess-17-4061-2013-supplement.pdf.}

Acknowledgements. This work was jointly supported by the EUFP7 project CEOP-AEGIS (grant number 212921) and by the Vietnam Ministry of Education and Training.

Edited by: M. Werner

\section{References}

Bamler, R.: The SRTM mission - A world-wide $30 \mathrm{~m}$ resolution DEM from SAR interferometry in 11 days. Proceedings of the 47th Photogrammetric Week '99, Wichmann Verlag, Heidelberg, Germany, 145-154, 1999.

Bolch, T., Yao, T., Kang, S., Buchroithner, M. F., Scherer, D., Maussion, F., Huintjes, E., and Schneider, C.: A glacier inventory for the western Nyainqentanglha Range and the Nam Co Basin, Tibet, and glacier changes 1976-2009, The Cryosphere, 4, 419433, doi:10.5194/tc-4-419-2010, 2010.

DeBarry, P. A.: Watersheds: Processes, Assessment and Management, John Wiley \& Sons, Inc., (Chapter 1), 2004.

Gardelle, J., Berthier, E., and Arnaud, Y.: Slight mass gain of Karakoram glaciers in the early twenty-first century, Nat. Geosci., 5, 322-325, doi:10.1038/NGEO1450, 2012.

GLCF: MODIS Water Mask, available at: http://landcover.org/data/ watermask, last access: 12 December 2012.

Immerzeel, W. W., Van Beek, L. P. H., and Bierkens, M. F. P.: Climate change will affect the Asian water towers, Science, 328, 1382-1385, 2010.

Kaab, A., Berthier, E., Nuth, C., Gardelle, J., and Arnaud, Y.: Contrasting patterns of early twenty-first-century glacier mass change in the Himalayas, Nature, 488, 495-498, 2012.

Krause, P., Biskop, S., Helmschrot, J., Flügel, W.-A., Kang, S., and Gao, T.: Hydrological system analysis and modelling of the Nam Co basin in Tibet, Adv. Geosci., 27, 29-36, doi:10.5194/adgeo27-29-2010, 2010.

Lehner, B., Verdin, K., and Jarvis, A.: New global hydrography derived from spaceborne elevation data, EOS T. Am. Geophzs. Un., 89, 93-94, 2008. 
O'Callaghan, J. F. and Mark, D. M.: The extraction of drainage networks from digital elevation data, Comput. Vision Graph., 28, 323-344, 1984.

Phan, V. H., Lindenbergh, R. C., and Menenti, M.: ICESat derived elevation changes of Tibetan lakes between 2003 and 2009, Int. J. Appl. Earth Obs., 17, 12-22, 2012a.

Phan, V. H., Lindenbergh, R. C., and Menenti, M.: Seasonal trends in Tibetan lake level changes as observed by ICESat laser altimetry. ISPRS - International Annals of the Photogrammetry, Remote Sensing and Spatial Information Sciences, 1, 237-242, 2012b.

Radic, V. and Hock, R.: Regionally differentiated contribution of mountain glaciers and ice caps to future sea-level rise, Nat. Geosci., 4, 91-94, 2011.

Shi, Y., Liu, C., and Kang, E.: The glacier Inventory of China, Ann. Glaciol., 50, 1-4, 2009.

Sinnott, R. W.: Virtues of the Haversine, Sky Telescope, 68, p. 159, 1984.

Sorg, A., Bolch, T., Stoffel, M., Solomina, O., and Beniston, M.: Climate change impacts on glaciers and runoff in Tien Shan (Central Asia), Nature Climate Change, 2, 725-731, 2012.

USGS: Hydrological data and maps based on Shuttle Elevation Derivatives at multiple Scales, available at: http://hydrosheds.cr. usgs.gov/index.php, last access: 12 December 2012.

Wang, P., Li, Z., and Gao, W.: Rapid shrinking of glaciers in the Middle Qilian Mountain region of Northwest China during the last $~ 50$ years, J. Earth Sci., 22, 539-548, 2011.

Wang, X., Gong, P., Zhao, Y., Xu, Y., Chang, X., Niu, Z.,Luo, Z., Huang, H., Sun, F., and Li, X.: Water-level changes in China's large lakes determined from ICESat/GLAS data, Remote Sens. Environ., 132, 131-144, 2013.
WDC, Chinese Glacier Inventory - World Data Center for Glaciology and Geocryology, Lanzhou, available at: http://wdcdgg.westgis.ac.cn/chinese/DATABASE/Glacier/ glacier_inventory.htm, last access: 12 December 2012.

Yao, T., Thompson, L., Yang, W., Yu, W., Gao, Y., Gou, X., Yang, X., Duan, K., Zhao, H., Xu, B., Pu, J., Lu, A., Xiang, Y., Kattel, D. B., and Joswiak, D.: Different glacier status with atmospheric circulations in Tibetan Plateau and surroundings, Nature Climate Change, 2, 663-667, 2012.

Ye, Q., Zhong, Z., Kang, S., Stein, A., Wei, Q., and Liu, J.: Monitoring glacier and supra-glacier lakes from space in Mt. Qomolangma Region of the Himalayas on the Tibetan plateau in China, J. Mt. Sci., 6, 211-220, 2009.

Zandbergen, P.: Applications of Shuttle Radar Topography Mission Elevation Data, Geography Compass, 2, 1404-1431, 2008.

Zhang, G. Q., Xie, H. J., Kang, S. C., Yi, D. H., and Ackley, S. F.: Monitoring lake level changes on the Tibetan Plateau using ICESat altimetry data (2003-2009), Remote Sens. Environ., 115, 1733-1742, 2011.

Zhang, G., Yao, T., Xie, H., Kang, S., and Lei, Y.: Increased mass over the Tibetan Plateau: From lakes or glaciers?, Geophys. Res. Lett., 40, 2125-2130, doi:10.1002/grl.50462, 2013.

Zhang, Y., Liu, S., Xu, J., and Shangguan, D.: Glacier change and glacier runoff variation in the Tuotuo River basin, the source region of Yangtze River in western China, Environ. Geol., 56, 5968, 2008

Zhou, S. Q., Kang, S. C., Gao, T. G., and Zhang, G. S.: Response of Zhadang Glacier runoff in Nam Co Basin, Tibet, to changes in air temperature and precipitation form, Chinese Science Bulletin, 55, 2103-2110, 2010. 